\title{
Fasting does not induce gastric emptying in rats ${ }^{1}$
}

\author{
Marcus Vinicius Henriques Brito ${ }^{\mathrm{I}}$, Edson Yuzur Yasojima ${ }^{\mathrm{II}}$, Renan Kleber Costa Teixeira ${ }^{\mathrm{III}}$, Abdallah de Paula Houat ${ }^{\mathrm{IV}}$, Vitor \\ Nagai Yamakiv, Felipe Lobato da Silva Costa ${ }^{\mathrm{VI}}$
}

DOI: http://dx.doi.org/10.1590/S0102-865020150030000001

IPhD, Full Professor, Head, Department of Integrate Health, Medical School, University State of Para (UEPA), Brazil. Conception and design of the study, manuscript writing, critical and final revision.

IIPhD, Full Professor, Department of General Surgery, UEPA, Brazil. Design of the study, critical revision.

II'MD, School of Medicine, UEPA. Brazil. Technical procedures, statistical analysis, manuscript preparation, English version.

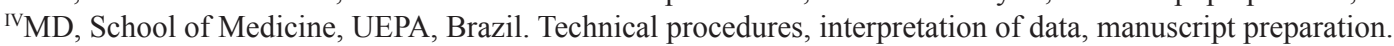

${ }^{\mathrm{v}}$ Graduate student, School of Medicine, UEPA. Brazil.Care of animals, technical procedures, manuscript preparation.

${ }^{\mathrm{VI}}$ Graduate student, School of Medicine, UEPA. Brazil. Care of animals, manuscript preparation, English version.

\begin{abstract}
PURPOSE: To evaluate the effect of fasting on gastric emptying in mice.

METHODS: Twenty-eight mice were distributed into three study groups: a normal group (N=4): normal standard animals; a total fasting group $(\mathrm{N}=12)$ : subjected to food and water deprivation and a partial fasting group $(\mathrm{N}=12)$ : subjected to food deprivation only. The fasting groups were subdivided into three subgroups of four animals each, according to the date of euthanasia: 24, 48 and 72 hours. Was analyzed: the gastric volume, degree of the gastric wall distention and the presence of food debris in gastrointestinal tract.

RESULTS: The mean gastric volume was $1601 \mathrm{~mm}^{3}$ in the normal group, $847 \mathrm{~mm}^{3}$ in total fasting group and $997 \mathrm{~mm}^{3}$ in partial fasting group. There was difference between the fasting groups in any analyzed period $(p<0.05)$. Regarding the presence of food debris in the gastrointestinal tract and the degree of distension of the stomach, there was no difference between the groups that underwent total or partial fasting $(\mathrm{p}>0.05)$.
\end{abstract}

CONCLUSION: Total fasting or only-solids deprivation does not induce gastric emptying in mice.

Key words: Fasting. Gastric Emptying. Mice. 


\section{Introduction}

The use of preoperative fasting is commonly adopted prior to the realization of several major surgeries. Such technique is instituted to ensure gastric emptying and avoid a possible aspiration during the anesthetic technique (Mendelson's syndrome) ${ }^{1}$.

However, there is evidence that small murines, such as rats and mice, do not exhibit the ability to vomit, and in case of fasting they have an eating disorder that involves the appetite perversion, demonstrated by eating non-food substances, such as soil and their bedding ${ }^{2,3}$. Thus, food deprivation becomes just a stress for the animal trial, and can influence in some experiments because of the changes in carbohydrate metabolism ${ }^{4}$.

The current ethical rules on animal research seek to minimize the pain and suffering of animals ${ }^{5,6}$, seeking mainly to avoid unnecessary procedures that would only cause stress. Thus, the practice of preoperative fasting could be a procedure eliminated in practice with small rodents if such technique is proofed to be unnecessary.

Some authors argues that the practice of preoperative fasting would decrease the amount of food debris in gastrointestinal tract $^{7-9}$. However, there is evidence suggesting that this practice is ineffective for such purpose, because that would be no gastrointestinal emptying without water and food intake. Thus, this study aims to evaluate the effects of fasting on gastric emptying in mice.

\section{Methods}

This research was approved by the Ethics Committee in the Use of Animals of the State University of Para (UEPA).

Twenty eight adults females mice (Mus musculus) were used, weighing between 40- 42 grams, provided from the Animal Colony of the Experimental Surgery Laboratory of UEPA, kept in a controlled environment. All animals had ad libitum access to food and water except during test periods. The animals were randomized distributed into three study groups:

-Control Group (CG): animals with regular $\operatorname{diet}(\mathrm{N}=4)$;

-Total Fasting Group (TFG): subjected to food and water deprivation $(\mathrm{N}=12)$;

-Partial Fasting Group (SFG): subjected to food deprivation only $(\mathrm{N}=12)$.

The fasting groups were subdivided into three subgroups of four animals each, according the time of elapsed until the animal euthanasia: 24,48 or 72 hours.

The animals were weighed twice: before starting the fasting period and on the day of euthanasia, to assess animal weight loss. The animals' euthanasia was performed by overdose of intraperitoneal xylazine. The euthanasia was achieved by xylazine overdose. After the confirmation of animal death, a median laparotomy was immediately performed to assess: the stomach volume, by measuring its dimensions; presence or absent of food debris in the gastrointestinal tract and the degree of gastric wall distension.

The degree of gastric wall distension was classified as 0 : collapsed walls; 1 : slightly distended; 2 : moderated distended; and 3: intense distended. Kruskal-Wallis test was used to compare the volume measurement and degree of distention of the gastric wall, Pearson's Linear Correlation test was used to verify the weight variation and Exact Fischer analysis for presence or absent of food debris in the gastrointestinal tract. Was adopted a significance level of $5 \%$ to reject the null hypothesis.

\section{Results}

The analysis of animal weight curve (Figure 1) shows that there was significant weight loss during the studied period $(\mathrm{p}<0.01)$. However, there was no significant difference between the weight loss of the animals when the type of fasting (total or partial) was compared.

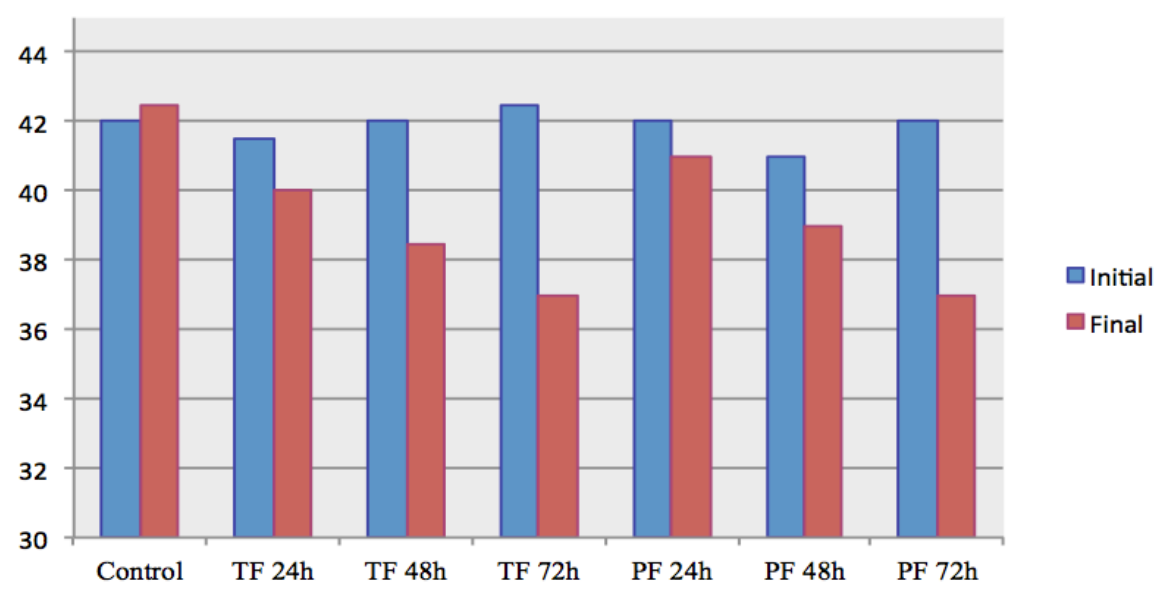

FIGURE 1 - Initial and final weight of the animals. TF - Total Fasting; PF - Partial Fasting 
In the analysis of the average volume of stomachs (Figure 2) was identified in the control group a volume of $1601 \mathrm{~mm}^{3} ; 814$ $\mathrm{mm}^{3}$ in the total fasting $\left(899 \mathrm{~mm}^{3}-24 \mathrm{~h} ; 796 \mathrm{~mm}^{3}-48 \mathrm{~h} ; 747\right.$ $\left.\mathrm{mm}^{3}-72 \mathrm{~h}\right)$; and was $997 \mathrm{~mm}^{3}$ in the partial fasting $\left(1153 \mathrm{~mm}^{3}-\right.$ 24h; $989 \mathrm{~mm}^{3}$ - 48h; $851 \mathrm{~mm}^{3}-72 \mathrm{~h}$ ).A significant difference was observed between the control group and fasting groups, where the average volume was higher in the control group $(\mathrm{p}<0.01)$. There was a significant difference between the two fasting groups, where the partial fasting group had higher stomach volume than the total fasting group $(\mathrm{p}<0.05)$. In both fasting groups there was a significant decrease of the stomach volume within the analyzed time periods $(\mathrm{p}<0.001)$.

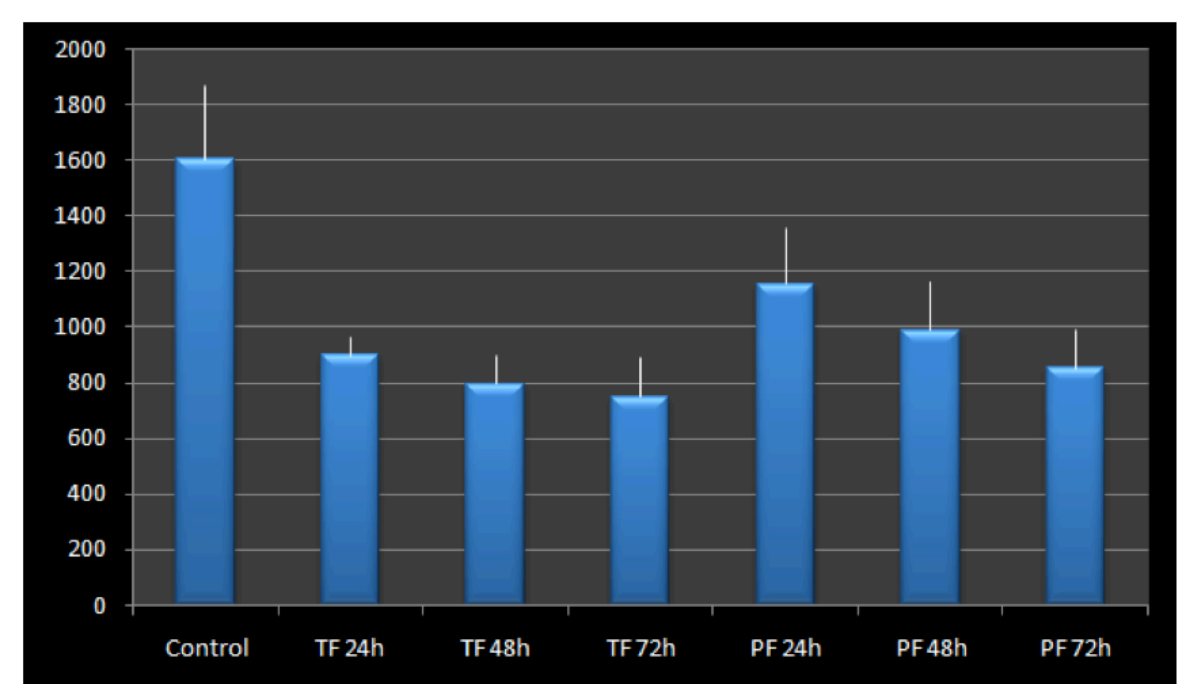

FIGURE 2 - Animals' stomach volume after fasting according to the experimental groups. TF - Total Fasting; PF - Partial Fasting

The average stomach distension degree of the CG was 3.00 ; in the total fasting group the degree was 2.00 (24 hours), 1.75 (48 hours) and 2.00 (72 hours); and in the partial fasting groups was 1.75 (24 hours), 2.00 (48 hours) and 2.00 (72 hours). There was a significant difference between the $\mathrm{CG}$ and the other groups $(p<0.05)$, but was not identified differences between groups that underwent partial or total fasting $(\mathrm{p}=0.96)$.

Table 1 shows the areas where food residues have been identified in the gastrointestinal tract of the animals. It shows that only in the control group was identified food debris in the small intestine and in all parts of the large intestine.

TABLE 1 - Amount of animals with presence/absence of food in the gastrointestinal tract according to the analyzed segment.

\begin{tabular}{|c|c|c|c|c|c|c|c|c|}
\hline & \multicolumn{2}{|c|}{ Stomach } & \multicolumn{2}{|c|}{ Small intestine } & \multicolumn{2}{|c|}{ Caecum } & \multicolumn{2}{|c|}{ Ascending and descending colon } \\
\hline & Present & Absent & Present & Absent & Present & Absent & Present & Absent \\
\hline Control & 4 & 0 & 4 & 0 & 4 & 0 & 4 & 0 \\
\hline TF $24 \mathrm{~h}$ & 4 & 0 & 0 & 4 & 4 & 0 & 4 & 0 \\
\hline TF $48 \mathrm{~h}$ & 4 & 0 & 0 & 4 & 4 & 0 & 2 & 2 \\
\hline TF $72 \mathrm{~h}$ & 4 & 0 & 0 & 4 & 4 & 0 & 0 & 4 \\
\hline PF 24h & 4 & 0 & 0 & 4 & 4 & 0 & 4 & 0 \\
\hline PF 48h & 4 & 0 & 0 & 4 & 4 & 0 & 1 & 3 \\
\hline PF 72h & 4 & 0 & 0 & 4 & 4 & 0 & 0 & 4 \\
\hline
\end{tabular}

Source: Protocol search

\section{Discussion}

The use of animals in experimental research is a practice that has been increasingly criticized over the past decades ${ }^{5,6,10}$.
In1959, Russell and Burch ${ }^{11}$ proposed the 3 R's theory in which all the experiments involving animals should seek for the "reduction" of the number of used animals; "replacement" of animals for validated alternative techniques; and "refinement" of the research 
conduction, where the methods should eliminate or at least reduce the pain and suffering of the animal.

Current evidence shows that preoperative fasting in small rodents is a procedure that is just stressful to animals, since these animals have no ability to vomit ${ }^{2,3}$ and do not present the risk of pulmonary aspiration of gastrointestinal contents even with full load of intragastric content as evidenced in this study.

Some reasons for the inability to vomit are: 1) diaphragmatic structure relatively less muscular ${ }^{3,12}$;2) esophagus length relatively longer than non-emetic species ${ }^{13}$; 3) stomach geometry with absence of a funnel shape $\mathrm{s}^{3}$; 4) absent brainstem neurological component of vomit ${ }^{3,14}$.

The presence of intragastric contents despite the loss of weight of the animal shows that the gastric income of solid food is a stimulant factor for gastric emptying in mice, whereas in the group with only water deprivation there was no increased gastric emptying than in the group subjected to water and food deprivation. In the control group, the greater gastric volume and presence of content in distal regions of the gastrointestinal elicit that there was gastric emptying associated to grater food intake. However, the difference between the fasting groups occurred probably due to simply hydration of the gastric contents ${ }^{15}$, giving the false impression of a larger quantity of food.

Unlike humans, whom are relatively used with large fasting periods, small rodents must keep gnawing to get food and to control the steady growth of their teeth ${ }^{16}$. Hence, this constant stimulation is a major stimulus to gastric emptying ${ }^{17-20}$ along with many hormones, such as cholecystokinin; and neural pathways, such as parasympathetic stimuli.

Another claimed reason for conducting the preoperative fasting in small rodents would be to perform a bowel cleansing. However, this study identified that after 24 hours fasting period there is feces content in the entire large intestine and only a more prolonged fasting period ( 72 hours) could deliver a satisfactory colon cleansing. However, an early fasting was considered sufficient to conduct a clean surgery of the small intestine.

Preoperative (24 hours) fasting showed that was not sufficient for proper bowel preparation ${ }^{21}$, and many related substances might have better results, such as polyvinylpyrrolidone ${ }^{22}$ and retrograde flushing ${ }^{23}$. The findings from this study suggest that fasting might be substituted by other techniques for gastrointestinal cleansing.

\section{Conclusion}

Total fasting or only-solids deprivation does not induce gastric emptying in mice, according the methods used.

\section{References}

1. Feguri GR, Lima PRL, Lopes AM, Roledo A, Marchese M, Trevisan M, Ahmad H, Freitas BB, Aguilar-Nascimento JE. Resultados clínicos e metabólicos da abreviação do jejum com carboidratos na revascularização cirúrgica do miocárdio. Rev Bras Cir Cardiovasc. 2012 Mar;27(1):7-17. doi: 10.5935/1678-9741.20120004.

2. Yamamoto K, Takeda N, Yamatodani A. Establishment of an animal model for radiation-induced vomiting in rats using pica. J Radiat Res. 2002 Mar;43:135-41.

3. Horn CC, Kimball BA, Wang H, Kaus J, Dienel S, Nagy A, Gathright GR, Yates BJ, Andrews PLR. Why Can't Rodents Vomit? A comparative behavioral, anatomical, and physiological study. PLoS ONE. 2013 April;8(6):60537 doi: 10.1371/journal.pone.0060537.

4. Wasselin T, Zahn S, Maho YL, Dorsselaer AV, Raclot T, Bertile F. Exacerbated oxidative stress in the fasting liver according to fuel partitioning. Proteomics. 2014 Aug;14(16):1905-21. doi: 10.1002/ pmic.201400051.

5. Miziara ID, Magalhães ATM, Santos MD, Gomes EF, Oliveira RA. Ética da pesquisa em modelos animais. Braz J Otorhinolaryngol. 2012 April;78(2):128-31. doi: 10.1590/S1808-86942012000200020.

6. Goldenberg S. Importância ética e moral da pesquisa experimental para a prática médica. Acta Cir Bras. 2011 Mar;26(2):80-1.

7. Damy SB, Camargo RS, Chammas R, Figuereido LFP. Aspectos fundamentais da experimentação animal - aplicações em cirurgia experimental. Rev Assoc Med Bras. 2010 Jan;56(1):103-11. doi: 10.1590/S0104-42302010000100024.

8. Soares Junior C, Souza C. The use of 2-octyl cyanoacrylate in colonic anastomosis: experimental study in Wistar rats. Rev Col Bras Cir. 2010;37(2):135-42. doi: 10.1590/S0100-69912010000200011.

9. Naresse LE, Leite CVS, Rodrigues MAM, Angeleli AYO, Minossi JG, Kobayasi S. Efeito da peritonite fecal na cicatrização do colon distal no rato. Avaliação anatomopatologica, estudo da força de rupture e da hidroxiprolina tecidual. Acta Cir Bras. 1993;8(2):48-53.

10. Kinshoku MR, Rodriguez CAL, Fidalgo RS, Duran CCG, Leme PLS, Duarte IS. Uso racional de modelos animais para pesquisa e ensino de microcirurgia. Rev Col Bras Cir. 2012 Oct;39(5):414-7. doi: 10.1590/S0100-69912012000500013.

11. Fraser D. A practical ethic for animals. J Agr Environ Ethic. 2012 July;25:1-26. doi: 10.1007/s10806-011-9353-z.

12. Pickering M, Jones JF. The diaphragm: two physiological muscles in one. J Anat. 2002 Oct;201(4):305-12. doi: 10.1046/j.14697580.2002.00095.x.

13. Andrews PLR. Why do some animals lack a vomiting reflex? Physiol Zoology. 1995;68:61.

14. Smith JE, Paton JF, Andrews PL. An arterially perfused decerebrate preparation of Suncusmurinus (house musk shrew) for the study of emesis and swallowing. J Exp Physiol. 2002 Sep;87:563-74. doi: 10.1113/eph8702424.

15. BaracatECE,CollaresEF.Gastricemptyingofliquidsinratsdehydrated by water deprivation.Braz J Med Biol Res. 1997 Nov;30(11):13639. doi: 10.1590/S0100-879X1997001100017.

16. Azambuja HV, Puricelli E, Ponzoni D. Evaluation of the application of a permanent buried magnetic field in area of bone allograft and dentoalveolar- experimental study in rats. Rev Facul Odont. 2011 May;16(2):187-92.

17. Verschueren S, Janssen P, Van Oudenhove L, Hultin L, Tack JF. The effect of pancreatic polypeptide on gastric accommodation and gastric emptying in conscious rats. Am J Physiol Gastrointest Liver Physiol. 2014 April;307(1):G122-8. doi: 10.1152/ajpgi.00043.2014.

18. Chambers AP, Smith EP, Begg DP, Grayson BE, Sisley S, Greer T, Sorrell J, Lemmen L, LaSance K, Woods SC, Seeley RJ, D'Alessio DA, Sandoval DA. Regulation of gastric emptying rate 
and its role in nutrient-induced GLP-1 secretion in rats after vertical sleeve gastrectomy. Am J Physiol Gastrointest Liver Physiol. 2014 Feb;306(4):E424-32. doi: 10.1152/ajpendo.00469.2013.

19. Dockray GJ. Gastrointestinal hormones and the dialogue between gut and brain. J Physiol. 2014 Jul 15;592(Pt 14):2927-41. doi: 10.1113/jphysiol.2014.270850.

20. Palheta Jr RC, Silva MTB, Barbosa HLG, Pinheiro ADN, Cardoso KVV, Graça JRV, Magalhães PJC, Oliveira RB, Santos AA. Atrial stretch delays gastric emptying of liquids in awake rats. Life Sci. 2013 Mar;92(10):596-75. doi: 10.1016/j.lfs.2013.01.016.

21. Regadas FSP, Figueiredo WR, Nogueira MAA, Bezerra CRS, Sousa PC. Role of bowel preparation on colocolonic anastomosis: experimental study in dogs. J Coloproctol. 2012 Dec;32(4):359-64. doi: 10.1590/S2237-93632012000400002.

22. Milagres LC, Araújo ID, Barral SM, Grossi GCX. Efeito do uso de povidine-iodine na cicatrização de anastomoses de cólon direito de ratos. Arq Gastroenterol. 2005 June;42(2):95-8. doi: 10.1590/ S0004-28032005000200006.

23. Bartoli R, Boix J, Òdena G, Moreno VV, Lorenzo-Zuñiga V. Determination of the ideal preparation for colonoscopy in a rat model. Surg Laparosc Endosc Percutan Tech. 2012 Dec;22(6):5425. doi: 10.1097/SLE.0b013e318264c4f9.

\section{Correspondence:}

Marcus Vinicius Henriques Brito

Rua Apinagés, 630/202

66.033-170 Belém - PA Brasil

Tel.: (55 91)3222-9752/8854-8895

marcusvhbrito@gmail.com

Received: Nov 17, 2014

Review: Jan 19, 2015

Accepted: Feb 16, 2015

Conflict of interest: none

Financial source: State University of Para

${ }^{1}$ Research performed at Experimental Surgery Laboratory, School of Medicine, State University of Para (UEPA), Belem-PA, Brazil. 